\title{
Кристаллическая структура и происхождение нового природного цирконосиликата $\mathrm{NaHZrSi}_{2} \mathrm{O}_{7}$
}

\author{
Яковенчук В.Н. ${ }^{1,2}$, Паникоровский Т.Л. ${ }^{3}$, Пахомовский Я.А. ${ }^{1,2}$, Иванюк Г.Ю. ${ }^{1,2}$, \\ Кривовичев С.B. ${ }^{2}$ \\ ${ }^{1}$ Геологический институт ФИЦ КНЦ РАН, Anamumbl, yakovenchuk@geoksc.apatity.ru, \\ pakhom@geoksc.apatity.ru \\ ${ }^{2}$ Центр наноматериаловедения ФИЦ КНЦ РАН, Anamumbl, g.ivanyuk@gmail.com; skrivovi@mail.ru \\ ${ }^{3}$ Лаборатория природоподобных технологий и техносферной безопасности Арктики ФИЦ КНЦ \\ PAH, Anamumbl,taras.panikorovsky@spbu.ru
}

Аннотация. Приводится описание новой природной фазы $\mathrm{NaHZrSi}_{2} \mathrm{O}_{7}$. Её структура решена в пространственной группе $P$-1 с $R$-фактором 0.12 для 911 независимых рефлексов $a=5.566(3), b=7.190(2)$, $c=7.614(3) \AA, \alpha=64.86(3), \beta=81.92(3), \gamma=89.16(3)^{\circ}, V=272.7(2) \AA^{3}$. Основу структуры составляет каркас из димеров рёберно-связанных октаэдров циркония, объединённых по общим вершинам с силикатными диортогруппами $\left[\mathrm{Si}_{2} \mathrm{O}_{7}\right]$. В пустотах каркаса располагаются атомы натрия.

Ключевые слова: новый цирконосиликат натрия, кристаллическая структура.

\section{Crystalline structure and origin of new zirconosilicate $\mathrm{NaHZrSi}_{2} \mathrm{O}_{7}$}

\author{
Yakovenchuk V.N. ${ }^{1,2}$, Panikorovskii T.L. ${ }^{3}$, Pakhomovsky Ya.A. ${ }^{1,2}$, Ivanyuk G.Yu. ${ }^{1,2}$, \\ Krivovichev S.V. ${ }^{2}$ \\ ${ }^{1}$ Geological institute FIC KSC RAS, Apatity, yakovenchuk@geoksc.apatity.ru \\ ${ }^{2}$ Nanomaterials Research Center FIC KSC RAS, Apatity,g.ivanyuk@gmail.com; skrivovi@mail.ru \\ ${ }^{3}$ Laboratory of geo-insired technologies and environmental safety of Arctic region FIC KSC RAS, Apatity, \\ taras.panikorovsky@spbu.ru
}

\begin{abstract}
The article contains description of a new natural phase $\mathrm{NaHZrSi}_{2} \mathrm{O}_{7}$. Its crystal structure is solved in the $P$-1 space group with $R$-factor 0.12 for 911 independent reflections $a=5.566(3), b=7.190(2), c=7.614(3) \AA$, $\alpha=64.86(3), \beta=81.92(3), \gamma=89.16(3)^{\circ}, V=272.7(2) \AA^{3}$. The crystal structure is based upon framework of dimers of edge-shared zirconium ochtahedra connected with nesosilicate $\left[\mathrm{Si}_{2} \mathrm{O}_{7}\right]$ groups by shared vertexes. The framework cavities contain sodium atoms.
\end{abstract}

Key words: new Na zirconosilicate, crystal structure.

\section{Введение}

Новая фаза была обнаружена в альбититах г. Тахтарвумчорр (Хибинский массив). Альбититы, заместившие фойяиты и эгирино-нефелино-микроклиновые пегматиты, сложены тонкомелкозернистым агрегатом пластинчатого альбита с линзами (до $1 \times 0.5$ м) сахаровидного апатита, в массу которого заключены уплощенно-призматические кристаллы энигматита, чешуйки и радиально-лучистые агрегаты молибденита, пластинки ильменита и пирротина, тёмно-оранжевые призматические кристаллы ловенита и сферолиты бледно-кремового волокнистого чирвинскиита. В постоянной ассоциации с чирвинскиитом находятся лимонно-жёлтые радиально-лучистые агрегаты и отдельные призматические кристаллы титанита, частично замещенного лоренценитом, зёрна эвдиалита и циркона, замещённые с краёв порошковатыми массами келдышита с включениями новой фазы $\mathrm{NaHZrSi}_{2} \mathrm{O}_{7}$, ранее описанной А.П. Хомяковым (1990) под названием M-34 (рис. 1).

В работе А.П. Хомякова отмечена возможность образования келдышитоподобных цирконосиликатов вследствие гидратации первичного паракелдышита: $\mathrm{Na}_{2} \mathrm{ZrSi}_{2} \mathrm{O}_{7}$ (паракелдышит) $\rightarrow$ $\mathrm{NaHZrSi}_{2} \mathrm{O}_{7}$ (M-34) $\rightarrow \mathrm{NaH}_{3} \mathrm{Zr}_{2}\left[\mathrm{Si}_{2} \mathrm{O}_{7}\right]_{2}$ (келдышит). Такая схема подразумевает преемственность структуры этих соединений, однако наша расшифровка структуры M-34 показала её кристаллохимическую уникальность. 


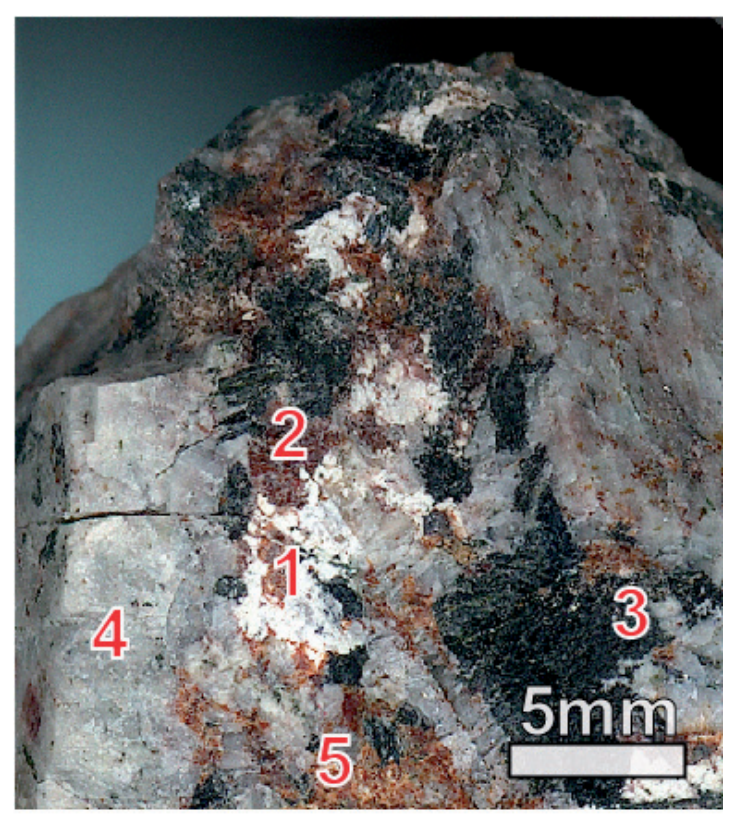

Рис. 1. Порошковатые агрегаты (пара)келдышита и фазы $\mathrm{NaHZrSi}_{2} \mathrm{O}_{7}$ (1) с эвдиалитом (2), эгирином (3), альбитом (4) и ловенитом (5) в альбитизированном пегматите фойяитов г. Тахтарвумчорр.

Fig. 1. Powder aggregates of a new phase $\mathrm{NaHZrSi}_{2} \mathrm{O}_{7}$ (1) with eudialyte (2), aegirine (3), albite (4) and lavenite (5) in albitized alkaline pegmatites in foyaite of Mt. Takhtarvumchorr.

\section{Эксперимент}

Рентгеноструктурный анализ монокристаллов природной фазы $\mathrm{NaHZrSi}_{2} \mathrm{O}_{7}$ проводился на дифрактометре Agilent Technologies Xcalibur EOS, оснащенного плоским CCD детектором, при комнатной температуре с использованием монохроматического МоК $\alpha$ излучения $(\lambda=0.71069 \AA)$. Параметры элементарной ячейки уточнялись методом наименьших квадратов. Поправка на поглощение определена эмпирически с помощью сферических гармоник, реализованных в алгоритме калибрования SCALE ABSPACK, в программном комплексе CrysalysPro (Agilent Technologies, 2014). Уточнение структуры проводилось с помощью программы SHELX (Sheldrick, 2015).

Кристаллическая структура (рис. 2) новой природной фазы с химическим составом NaHZr$\mathrm{Si}_{2} \mathrm{O}_{7}$ была решена впервые в пространственной группе $P-1$ с $R$-фактором 0.12 для 911 рефлексов. Параметры элементарной ячейки приведены в таблице в сравнении с таковыми келдышита и паракелдышита. В этой структуре октаэдры $\mathrm{ZrO}_{6}$ объединены парами по общим ребрам вместе с крупными октаэдрами натрия, полимеризуясь в октаэдрические слои, к которым с обеих сторон примыкают силикатные диортогруппы (см. рис. 2).

Следует отметить, что в основе кристаллических структур (пара)келдышита, лежат одиночные Zr-центрированные октаэдры, объединенные диортогруппами т.е. они существенно отличается от изученной нами структуры M-34. Присутствие последней фазы ставит под собой сомнение существование трансформационной цепочки паракелдышит-келдышит-М-34, поскольку келдышит $\mathrm{NaH}_{3} \mathrm{Zr}_{2}\left[\mathrm{Si}_{2} \mathrm{O}_{7}\right]_{2}$ и паракелдышит $\mathrm{Na}_{2} \mathrm{ZrSi}_{2} \mathrm{O}_{7}$ изоструктурны между собой, а промежуточный между ними по составу и времени образования минерал не может обладать принципиально иной структурой.

Таблица. Химические формулы и параметры элементарных ячеек для поздних цирконосиликатов в пегматитах г. Тахтарвумчорр.

Table. Chemical formula and unit cell parameters for late zirconisilicate minerals in pegmatites of Mt. Takhtarvumchorr.

\begin{tabular}{|c|c|c|}
\hline Минерал & Формула & Параметры элементарной ячейки \\
\hline \multirow{2}{*}{ Келдышит } & \multirow{2}{*}{$\mathrm{NaH}_{3} \mathrm{Zr}_{2}\left[\mathrm{Si}_{2} \mathrm{O}_{7}\right]_{2}$} & $\mathrm{a}=9.01 \AA, \mathrm{b}=5.34 \AA, \mathrm{c}=6.96 \AA$ \\
\hline & & $\alpha=92.1^{\circ}, \beta=116.1^{\circ}, \gamma=88.1$ \\
\hline \multirow{2}{*}{ Паракелдышит } & \multirow{2}{*}{$\mathrm{Na}_{2} \mathrm{ZrSi}_{2} \mathrm{O}_{7}$} & $\mathrm{a}=6.62 \AA, \mathrm{b}=8.81 \AA, \mathrm{c}=5.43 \AA$ \\
\hline & & $\alpha=92.7^{\circ}, \beta=94.23^{\circ}, \gamma=71.46^{\circ}$ \\
\hline \multirow{2}{*}{ M-34 } & \multirow{2}{*}{$\mathrm{NaHZrSi}_{2} \mathrm{O}_{7}$} & $\mathrm{a}=5.566 \AA, \mathrm{b}=7.190 \AA, \mathrm{c}=7.614 \AA$ \\
\hline & & $\alpha=64.86^{\circ}, \beta=81.92^{\circ}, \gamma=89.16^{\circ}$ \\
\hline
\end{tabular}



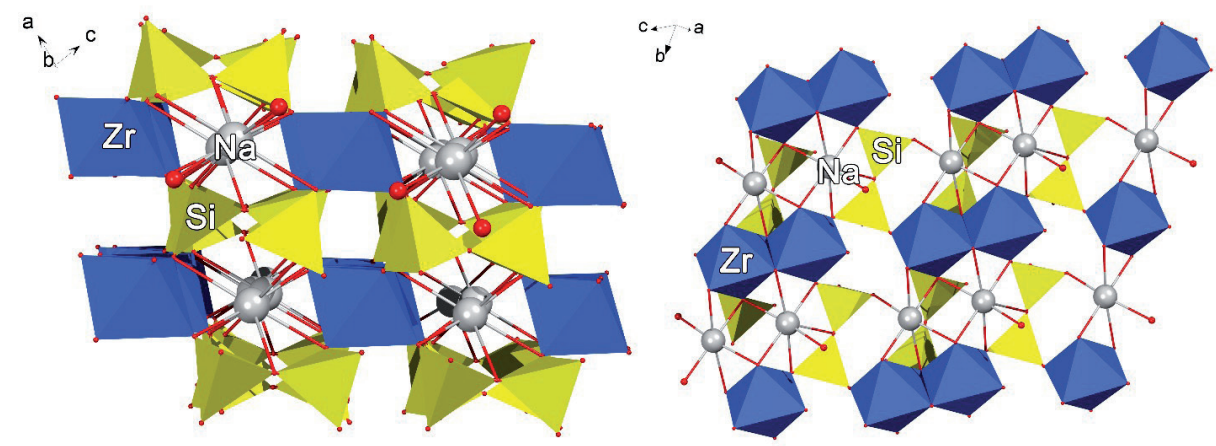

Рис. 2. Кристаллическая структура М-34 в проекция вдоль оси $b$ (слева) и в плоскости гетерополиэдрического цирконосиликатного слоя (справа).

Fig. 2. Crystalline structure M-34 in projection along $b$ axis (left) and on heteropolyhedral zirconium silicate layer (right).

\section{Обсуждение}

Образование фазы $\mathrm{NaHZrSi}_{2} \mathrm{O}_{7}$ и (пара)келдышита, вероятно, обусловлено преобразованием более раннего эвдиалита высоконатриевыми гидротермальными растворами в ходе альбитизации фойяитов и их пегматитов. Одновременно происходило образование лоренцинита и чирвинскиита вследствие изменения титанита. Таким образом, можно написать предполагаемую реакцию образования новой фазы:

$$
\mathrm{Lvt}+4 \mathrm{Ttn}+2 \mathrm{Eud}+10 \mathrm{Na}^{+}+7 \mathrm{H}_{2} \mathrm{O}=\mathrm{Chv}+2 \mathrm{Ti}+\mathrm{Ca}^{2+}+\mathrm{M}-34+\mathrm{Kd}+\mathrm{Pkd}
$$

где Chv - чирвинскиит, Lvt - ловенит, Eud - эвдиалит, Ttn- титанит, M-34 - фаза $\mathrm{NaHZrSi}_{2} \mathrm{O}_{7}$, a Kd и $\mathrm{Pkd}$ - келдышит и паракелдышит, соответсвенно. Соотношение паракелдышита и келдышита, повидимому, соответствует трансформационной схеме А.П. Хомякова, тогда как М-34 является либо самостоятельной фазой, либо альтернативным продуктом изменения паракелдышита.

Исследования проводились в рамках научных тем ФИЦ КНЦ РАН 0226-2019-0051, и 0226-2018-0003 (Программа Президиума РАН I-48).

\section{Литература}

1. Хомяков А.П. Минералогия ультраагпаитовых щелочных пород. М.: Наука. 1990. 195 с.

2. Agilent Technologies (2014) CrysAlis CCD and CrysAlis RED. Oxford Diffraction Ltd, Yarnton, Oxfordshire, UK.

3. Sheldrick, G.M. (2015). SHELXT - Integrated space-group and crystal-structure determination // Acta Cryst. A 71. P. 3-8. 